\title{
Evolution of leadership theory
}

\author{
Sihame Benmira (10, ${ }^{1}$ Moyosolu Agboola ${ }^{2}$
}

Mayo Clinic Healthcare, London, UK

2Virgin Care, Reading, UK

Correspondence to Dr Sihame Benmira, Mayo Clinic Healthcare, London W1B 1PT, UK;

sihame.benmira@doctors.org.uk

Received 26 May 2020 Revised 5 December 2020 Accepted 12 December 2020 Published Online First 8 January 2021

\section{Check for updates}

(c) Author(s) (or their employer(s)) 2021. No commercial re-use. See rights and permissions. Published by BMJ.

To cite: Benmira $S$, Agboola M. BMJ Leader 2021;5:3-5.

\section{INTRODUCTION}

Leadership is one of the most complex and multidimensional phenomena. It has been studied extensively over the years and has taken on greater importance than ever before in today's fast-paced and increasingly globalised world. Nonetheless, leadership continues to generate captivating and confusing debate due to the complexity of the subject. Bennis notes that 'leadership is the most studied and least understood topic of any in the social sciences' and 'never have so many laboured so long to say so little'. ${ }^{1}$

Researchers have proposed many different definitions and theories of leadership. Stogdill defines it as 'an influencing process aimed at goal achievement', focusing on leadership as a process directed at influencing a specific group of people to meet a stated objective. ${ }^{2}$ Kouzes and Posner similarly believe that 'leadership is the art of mobilising others to want to struggle for the shared aspirations ${ }^{3}$ and Maxwell states that leadership is simply influence. ${ }^{4}$ Yet there is no one definition or particular leadership approach that is considered universal and efforts continue in trying to identify what makes an effective leader.

Effective leadership is recognised as key to the success of any organisation. In fact, there has been a shift towards acknowledging the importance of human capital and organisational management. ${ }^{56}$ But what is the difference between leadership and management? Leaders are generally viewed as visionaries and strategist whereas managers monitor and control performance, maintaining order and stability in an organisation. ${ }^{78}$ Some researchers argue that leaders and managers have distinct roles and responsibilities while others assert that leadership and management are complementary and it would be difficult to separate them in practice.

The present paper traces the historical evolution of the main leadership theories and reviews the progress that has been made over the years. It explores four main eras in leadership theory: trait, behavioural, situational and new leadership.

\section{Trait era: Great Man theory (1840s) and trait theories (1930s-1940s)}

In the 19th century, research on leadership was focused on the innate characteristics of a leader ${ }^{9} 10$ and on identifying the personality traits and other qualities of effective leaders. ${ }^{11}$

The core belief of the Great Man theory is that leaders are born, not made or trained. In other words only a few, very rare, individuals possess the unique characteristics to be effective leaders and attain greatness by divine design. Examples were often drawn from popular historical figures such as
Julius Caesar, Mahatma Gandhi, Abraham Lincoln and Napoleon Bonaparte. It was believed that these individuals were natural born leaders with innate characteristics of leadership, which enabled them to lead individuals while they shape the pages of history.

The Great Man theory then evolved into the trait theories. Trait theories argue that leaders can be born or made. ${ }^{7}$ In other words, that the traits of successful leaders can be either inherited or acquired through training and practice. The aim was to identify the right combination of characteristics that make an effective leader and focus was on studying the mental, social and physical traits of leaders. However, a consistent set of traits was not produced and by 1950 , it appeared that there was little advantage in continuing with this approach and hence it was abandoned. Today, psychometric tools are an example of trait theory principles in action and are often used in staff recruitment. These tools highlight key personality traits and are used for personal performance and team development.

\section{Behavioural era: behavioural theory (1940s-1950s)}

Behavioural theory evolved from trait theories and asserts that leaders are largely made, rather than born and that particular behaviours can be learnt to ensure effective leadership. ${ }^{11}{ }^{12}$ It puts emphasis on the actual behaviour of the leader and not on their traits or characteristics, but it largely ignores the situation and environment of the leader.

Research in this area resulted in different patterns of behaviour being grouped together and labelled as styles. ${ }^{11}$ This became a prevalent approach within management training-perhaps the best known being Blake and Mouton's Managerial Grid. ${ }^{13}$ Today, this theory is exemplified in the numerous leadership-training programmes, which involve the development of leadership skills and behaviours, thus supporting the belief that leadership is largely learnt.

\section{Situational era: contingent and situational theories (1960s)}

It was later recognised that the environment plays a significant role in the leader-follower dynamic and this belief dominated the situational era. ${ }^{14}$ As the name suggests, the situational era is focused on leadership in particular situations, rather than on the traits or behaviours of leaders. This implies that leaders must be able to assess the context in which they operate and then decide what style will 'fit' the situation best. Because the best style is dependent on the situation, this approach is known as the contingency theory of leadership. 
The Learning Zone

\begin{tabular}{llll}
\hline \multicolumn{2}{l}{ Table 1} & Summary of the main leadership theories & \\
\hline Era & Period & Theory & Description \\
\hline Trait & $1840 \mathrm{~s}$ & Great Man & Focus on natural born leaders \\
& $1930 \mathrm{~s}-1940 \mathrm{~s}$ & Trait & Focus on identifying traits and characteristics of effective leaders \\
Behavioural & $1940 \mathrm{~s}-1950 \mathrm{~s}$ & Behavioural & Focus on the actions and skills of leaders \\
Situational & $1960 \mathrm{~s}$ & $\begin{array}{l}\text { Contingent and } \\
\text { Situational }\end{array}$ & Focus on leaders adapting their style taking into account the environment \\
& Transactional & Focus on leadership as a cost-benefit exchange \\
New leadership & $1990 \mathrm{~s}$ & Transformational & Focus on an inspirational style pushing followers to higher and higher levels of \\
& Shared & achievement \\
& $2000 \mathrm{~s}$ & Collaborative & Focus on followers leading each other \\
& $2000 \mathrm{~s}$ & Focus on engaging followers. Person-centred style \\
& $2000 \mathrm{~s}$ & Focus on the whole system of an organisation \\
& Inclusive & \\
& Complexity & \\
& &
\end{tabular}

Fred Fiedler developed one of the first contingency theories of leadership. ${ }^{15}$ His theory focuses on the importance of context in effective leadership and supports the belief that there is no one best set of leadership traits or behaviours. However, Fiedler asserst that because a leader's style is fixed, they should be put into situations that best match their style. In other words, effectiveness as a leader is determined by how well their leadership style matches a particular context.

\section{New leadership era: transactional, transformational theories (1990s) and others (2000s)}

For the first time, it was recognised that focusing on one aspect or dimension of leadership cannot address all the complexity of the phenomenon. ${ }^{16}$ In a world that has become more complex and challenging, a need emerged for leadership theories that support circumstances of rapid change, disruptive technological innovation and increasing globalisation. This led to the new leadership era, moving away from the above-mentioned traditional theories of leadership, which define leadership as a unidirectional, top-down influencing process, drawing a distinct line between leaders and followers. Instead, the focus became on the complex interactions among the leader, the followers, the situation and the system as a whole, with particular attention dedicated to the latent leadership capacities of followers.

\section{Transactional and transformational theories}

The above-mentioned context encouraged the popularity and adoption of two leadership theories: transformational and transactional theories, ${ }^{17}$ and also gave rise to approaches such as the Lean strategy ${ }^{18}$ and agile methodology ${ }^{19}$ to help deal with the fast pace of change and increasing complexity of the challenges faced. Transformational leadership is a theory in which leaders encourage, inspire and motivate followers. ${ }^{20}$ This theory is used when an organisation needs to be revitalised, is undergoing significant change or requires a new direction. It is especially vital to today's fast-paced technological industry where innovation and agility can make or break an organisation. Examples of transformational leaders include the likes of Jeff Bezos, Steve Jobs and Bill Gates.

Transactional leadership, on the other hand, relies on authority to motivate employees. ${ }^{20}$ The leader exchanges reward for follower effort and punishes any follower who fails to meet their goals. In this context, the follower's perception concerning fairness and equity of the exchange with the leader is vital. ${ }^{21}$ Transactional leadership works best in mature organisations that already have clearly defined structure and goals, to keep them on track, and reinforce the status quo. Examples of transactional leaders include managers, who tend to focus on supervision, processes and follower performance.

\section{Others}

The continued shift in leadership concepts led to the development of shared, collective and collaborative leadership practices. $^{22} 23$ According to these, success in an organisation is more dependent on coordinative leadership practices distributed throughout the organisation rather than the actions of a few individuals at the top. Servant leadership became popular once again, emphasising the importance of followers. Servant leaders seek to support their team members and are most concerned with serving people first. ${ }^{24}$ More recently, inclusive leadership also emerged, focusing on a person-centred approach. ${ }^{25}$ It is based on the dynamic processes that occur between leaders and followers and focuses on empowering followers to becoming leaders. Finally, contemporary leadership theory also includes complexity leadership, which emerged as a means to deal with the complexity of our modern world. This theory takes a wholesystem view, considering contextual interactions that occur across an entire social system. ${ }^{26}$

\section{CONCLUSION}

Leadership theory is a dynamic phenomenon and continues to change over time. It has been studied extensively over the years and several theories have emerged (table 1). Traditional leadership theories include the Great Man theory, which maintains that leaders are born to lead thus possessing certain inherent

\section{Express checkout}

The present paper explores the historical evolution of leadership theory, which includes four main eras: trait, behavioural, situational and new leadership. The focus was initially on natural born leaders and identifying the traits of the effective leader. Behavioural leadership then followed and focused on the actions of a leader. The situational and contingent theories in turn assert that the best leadership style is the one that best fits a given context. These traditional leadership theories offered part of the answer to the leadership puzzle but none had all the answer. These were then followed by the new leadership theories, which are inclusive of additional factors, generally adopt a more systemic approach to leadership and take into account the multifaceted and complex nature of our modern world and the importance of followership in effective leadership. 


\section{In practice}

Hospital trusts in the UK are large, complex, and mature organisations within the National Health Service (NHS) with established structures and processes. Traditional leadership theory tells us that transactional leadership is ideal in this situation for keeping an established organisation on track, maintaining the status quo and ensuring the execution of plans. Transactional leadership is also known to be effective in guiding efficiency decisions, which are aimed at cutting costs and improving productivity. However, because the NHS is not only a mature organisation but also undergoing tremendous change, leaders may switch styles and adopt a transformational leadership approach to engage followers in implementing change and encouraging innovation.

Healthcare organisations may also benefit from the application of other more contemporary leadership theories such as collaborative, inclusive and shared leadership, which blur the distinction between leader and follower and adopt a person-centred approach that focuses on the empowerment and development of followers. Compassionate leadership is also relevant in the context of patient care. And complexity leadership theory can also help the NHS understand how to thrive in today's uncertain and turbulent times using a process-orientated, contextual and interactive approach to infiltrate leadership at all levels. The challenge is for healthcare professionals to be able to recognise which leadership theory is most relevant to their clinical practice and know how to effectively apply these theories in the workplace.

characteristics that destines them to lead. Trait theory evolved from the Great Man theory and specifies that leaders are can be born or made and that the combination of certain characteristics is needed to be an effective leader. Behavioural theory then followed, asserting that leaders are largely made with a focus on the actions of the leader as opposed to their personality traits. There was then recognition that certain environmental factors are important and contingency and situational theories were added to the mix. The modern era followed and involved a shift from focusing on the leaders and their attributes to considering the complex and continuous interactions and interrelationships among the leader, the followers and the situation. The resulting theories include shared, collective and collaborative leadership as well as inclusive leadership. Finally, complexity leadership also emerged, focusing on the whole system of an organisation.

Examining the historical development of leadership theories provides some necessary perspective as well as context within which to appreciate the complexity of the subject. Each theory has its merits and drawbacks and seems to provide part of the answer to the leadership puzzle. In today's complex, dynamic and globalised world, organisations are consistently dealing with change and uncertainty and no one theory has been able to address all the concerns regarding leadership. Many consider the traditional hierarchical views of leadership as less and less relevant given the complexity of our modern world. This led to a shift in focus from the characteristics and behaviours of leaders to a more systemic perspective, focusing on leadership as a collective social process resulting from the interactions of multiple factors. New leadership theories were consequently formulated in an attempt to deal with the new reality of organisations and business, resulting in newer and more relevant definitions of leader, follower and situation.

Contributors SB conceived the idea for the article. SB and MA contributed to the design and wrote the article. SB submitted the article. Both SB and MA contributed to revising the article following reviewer feedback.

Funding The authors have not declared a specific grant for this research from any funding agency in the public, commercial or not-for-profit sectors.

Competing interests None declared.

Patient consent for publication Not required.

ORCID iD

Sihame Benmira http://orcid.org/0000-0003-1681-4706

\section{REFERENCES}

1 Bennis WG. On becoming a leader. New York, NY: Basic Books, 2009.

2 Stogdill RM. Leadership, membership and organization. Psychol Bull 1950;47:1-14.

3 Kouzes J, Posner B. The leadership challenge: how to keep getting extraordinary things done in organisations. San Francisco: Jossey-Bass, 1995.

4 Maxwell J. Developing the leader within you. Nashville, TN: Injoy Inc, 1993.

5 Froiland JM. Employee retention. Great Neck Publishing, 2019.

6 Bhattacharyya SS. Development of a conceptual framework on real options theory for strategic human resource management. ICT 2018;50:272-84.

7 Buchanan DA, Huczynski A. Organizational behaviour. Ninth edition ed. Harlow: Pearson Education Limited, 2017: xxxvii, 813 pages $p$.

8 Swanwick T. Leadership and management: what's the difference? BMJ Leader 2019;3:99-100.

9 Cawthon DL. Leadership: the great man theory revisited. Business Horizons 1996;39:1-4.

10 Dziak M. Great man theory. Salem Press, 2019

11 Johns HE, Moser HR. From trait to transformation: the evolution of leadership theories. Education 1989;110:115.

12 Denison DR, Hooijberg R, Quinn RE. Paradox and performance: toward a theory of behavioral complexity in managerial leadership. Organization Science 1995;6:524-40.

13 Blake RR, Mouton JS. The board grid: an interview with Blake and Mouton. MLR Holdings LLC d/b/a Directors \& Boards, 1980: 19-27.

14 Yurii S, Yevgen M, Nataliia L. Evolution and modern tendencies in the theory of leadership. Baltic Journal of Economic Studies 2018;4:304-10.

15 Fiedler F, Chemers M. Leadership and effective management. Glenview: Scott Foresman, 1974.

16 Van Seters DA, Field RHG. The evolution of leadership theory. J Organ Chang Manag 1990:3:29-45

17 Bass BM. From transactional to transformational leadership: learning to share the vision. Organ Dyn 1990;18:19-31.

18 Collis D. Lean strategy. Business Today 2016;25:108.

19 Codington-Lacerte C. Agile software development. Salem Press, 2020.

20 Flynn SI. Transformational and Transactional leadership. Great Neck Publishing, 2019.

21 Hollander EP, Offermann LR. Power and leadership in organizations: relationships in transition. Am Psychol 1990;45:179-89.

22 Kukenberger MR, D'Innocenzo L. The building blocks of shared leadership: the interactive effects of diversity types, team climate, and time. Pers Psychol 2020;73:125-50

23 Lee-Davies L. Collaborative leadership skills : the contribution of a shared leadership model in sustaining leadership longevity University of Chester; 2013.

24 Eliot JL. Resilient leadership: the impact of a servant leader on the resilience of their followers. Adv Dev Hum Resour 2020;22:404-18.

25 Thompson $\mathrm{H}$, Matkin $\mathrm{G}$. The evolution of inclusive leadership studies: a literature review. Journal of Leadership Education 2020;19:15-31.

26 Rosenhead J, Franco LA, Grint K, et al. Complexity theory and leadership practice: a review, a critique, and some recommendations. Leadersh Q 2019;30:101304. 